\title{
АНАЛИЗ ПРОДОВОЛЬСТВЕННОГО ЗЕРНА В РОССИЙСКОЙ ФЕДЕРАЦИИ НА ЗАГРЯЗНЕННОСТЬ ШИРОКИМ СПЕКТРОМ МИКОТОКСИНОВ (НА ПРИМЕРЕ УРОЖАЯ 2018 ГОДА)*
}

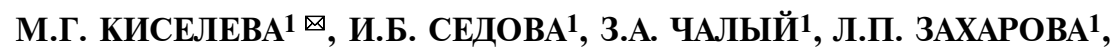 \\ Т.В. АРИСТАРХОВА 1 , В.А. ТУТЕЛЬЯН ${ }^{1,2}$
}

\begin{abstract}
Изучение совместной контаминации продовольственного зерна микотоксинами, накопление и анализ данных об уровнях и частоте их обнаружения является основой для оценки риска здоровью населения и разработки мер для его снижения. В настоящей работе впервые представлены данные о загрязненности продовольственного зерна пшеницы, кукурузы, ячменя, овса и ржи 28 микотоксинами. В их число вошли регламентируемые в продовольственном зерне микотоксины дезоксиниваленол (ДОН), Т-2 токсин (Т-2), зеараленон (ЗЕА), фумонизины В1 и В2 (ФВ1, ФВ2), афлатоксин В1 (АФЛ В1), охратоксин А (ОТА), их структурные производные (3- и 15-ацетилдезоксиниваленол (3- и 15-АџДОН), ниваленол (НИВ), фузаренон Х (ФУЗХ), НТ-2 токсин (НТ2), Т-2 триол, неосоланиол (НЕОС), $\alpha$ - и $\beta$-зеараленол ( $\alpha$ - и $\beta$-ЗЕЛ), афлатоксины В2, G1, G2 (АФЛ В2, G1, G2), стеригматоцистин (СТЦ)), микотоксины грибов рода Alternaria тентоксин (ТЕ), альтенуен (АЛТ), альтернариол (АОН) и его метиловый эфир (АМЭ), а также цитринин (ЦИТ), цитреовиридин (ЦТВ), микофеноловая (МФК) и циклопиазоновая (ЦПК) кислоты. Методом высокоэффективной жидкостной хроматографии в сочетании с тандемным масс-спектрометрическим детектированием (ВЭЖХ-МС/МС) проанализировано 162 образца зерна урожая 2018 года из семи федеральных округов Российской Федерации - Центрального, Приволжского, Уральского, Сибирского, Дальневосточного, Южного и Северо-Кавказского. В продовольственном зерне пшеницы из Центрального, Приволжского, Уральского и Сибирского ФО превалировали альтернариатоксины, в образцах из Краснодарского края - фузариотоксин ДОН. Помимо них образцы были контаминированы Т-2 и НТ-2 токсинами, ОТА, ЦИТ, ЗЕА и МФК. В образцах зерна кукурузы из Южного и Северо-Кавказского ФО основными контаминантами оказались фумонизины (ФВ1 или ФВ1 + ФВ2) и ДОН (ДОН или ДОН + 15-АџДОН). В трети образцов обнаружили МФК и HEОС. Токсины Alternaria в зерне кукурузы детектированы не были. Среди фузариотоксинов в зерне ячменя присутствовали Т-2 и НТ-2, в образцах из южных регионов России - также ФВ1, а токсины Alternaria оказались более характерны для образцов из Центрального, Приволжского, Уральского и Сибирского федеральных округов. В образцах зерна ржи и овса, вне зависимости от региона, чаще других микотоксинов обнаруживали альтернариатоксины; также детектировали Т-2 и НТ-2, НЕОС, ЦИТ. Исследованные образцы ячменя, овса и ржи не были контаминированы ДОН даже в следовых количествах. Впервые получены данные об обнаружении ЦТВ в продовольственном зерне пшеницы, ячменя и кукурузы. Таким образом, микотоксикологический скрининг позволил выявить микотоксины, наиболее характерные для региона произрастания и вида культуры. Полученные для продовольственного зерна результаты хорошо коррелируют с имеющимися данными о зараженности отечественного зерна продуцентами микотоксинов и контаминации непродовольственного зерна. С точки зрения безопасности для потребителя обращает на себя внимание высокая частота обнаружения ОТА $(7,4 \%$ всех исследованных образцов) и превышение максимально допустимого уровня в 45 \% положительных проб.
\end{abstract}

Ключевые слова: пшеница, ячмень, кукуруза, рожь, овес, микотоксины, дезоксиниваленол, Т-2 токсин, зеараленон, фумонизины, афлатоксины, охратоксин, ниваленол, фузаренон X, НТ-2 токсин, Т-2 триол, неосоланиол, зеараленолы, стеригматоцистин, тентоксин, альтенуен, альтернариол, цитринин, цитреовиридин, микофеноловая кислота, циклопиазоновая кислота, совместная контаминация, ВЭЖХ-МС/МС.

Микотоксины (вторичные метаболиты микроскопических грибов) это неизбежные природные контаминанты агропродукции. Случаи микотоксикозов людей и животных были зафиксированы в Японии, Бразилии, США, Европе, Китае, Советском Союзе, странах Африки (1). Описано несколько сотен микотоксинов, они обладают неодинаковым токсическим действием и различаются по распространенности и способности к накоп-

\footnotetext{
* Исследование выполнено в рамках НИР 0529-2018-0113 «Развитие методической и нормативной базы для обеспечения современных требований к качеству пищевой продукции и разработка технологий оценки эффективности специализированных пищевых продуктов».
} 
лению в субстратах разного происхождения. Наибольшую опасность для здоровья человека представляют фузариотоксины дезоксиниваленол (ДОН), Т-2 токсин, зеараленон (ЗЕА), фумонизины В1 и В2 (ФВ1 и ФВ2), а также метаболиты грибов родов Aspergillus и Penicillium - афлатоксин В1 (АФЛ В1) и охратоксин А (ОТА). Во многих странах установлены максимальные допустимые уровни (МДУ) содержания этих микотоксинов в продовольственном зерне и продуктах его переработки. В странах Таможенного союза действуют технические регламенты $(2,3)$, согласно которым в продовольственном зерне МДУ ДОН для пшеницы и ячменя составляет соответственно 700 и 1000 мкг/кг, Т-2 токсина для зерна любого вида - 100 мкг/кг. Содержание ЗЕА в зерне пшеницы, ячменя и кукурузы не может превышать 1000 мкг/кг, а суммарная концентрация ФВ1 и ФВ2 в кукурузе - 4000 мкг/Кг. МДУ для АФЛ В1 и ОТА составляет 5 мкг/кг.

Развитие аналитических методов позволило в последнее десятилетие значительно расширить круг определяемых микотоксинов. Благодаря применению в аналитической практике универсального, чувствительного и селективного метода высокоэффективной жидкостной хроматографии в сочетании с тандемным масс-спектрометрическим детектированием (ВЭЖХ$\mathrm{MC} / \mathrm{MC}$ ) появилась возможность одновременно детектировать десятки (4$6)$ и даже сотни $(7,8)$ вторичных метаболитов микроскопических грибов.

В зависимости от структуры, распространенности и опасности для человека можно условно выделить несколько групп микотоксинов: регламентируемые микотоксины и их структурные производные, токсины Alternaria и другие микотоксины, распространенность которых в пищевых продуктах растительного происхождения изучена неполно. Структурные производные обычно сопутствуют регламентируемым микотоксинам, а поскольку большинство из них также обладает токсическим действием, то для оценки безопасности пищевых продуктов устанавливают групповые МДУ или величины условно переносимого суточного поступления (УПСП). Например, в странах ЕС в пищевых продуктах регламентируется содержание не только АФЛ В1, но и суммы АФЛ (АФЛ $\mathrm{B}_{1}+\mathrm{B}_{2}+\mathrm{G}_{1}+\mathrm{G}_{2}$ ) (9). Значения УПСП установлены для ДОН и его производных (3-АщДОН, 15АцДОН и ДОН-3-глюкозида) (10), Т-2 токсина и его производных (НТ-2 токсин, диацетоксискирпенол, Т-2 триол и тетраол, неосоланиол - НЕОС, их гликозиды) (11), ЗЕА и его производных (гликозиды и сульфаты 3ЕА, $\alpha$ и $\beta$-зеараленолы ( $\alpha$-ЗЕЛ и $\beta$-ЗЕЛ) и др.) (12), фумонизинов (ФВ1, ФВ $2, \Phi_{3}$ и ФВ4) (13). Среди вторичных метаболитов грибов рода Alternaria чаще других в зерне выявляют альтернариол (АОН) и его метиловый эфир (АМЭ), тентоксин (ТЕ), альтенуен (АЛТ), тенуазоновую кислоту, альтертоксины, их модифицированные формы. Применение ВЭЖХ-МС/МС позволяет одновременно с перечисленными выше микотоксинами определять малоизученные - монилиформин, энниатины, боверицин, стеригматоцистин (СТЦ), микофеноловую кислоту (МФК), цитреовиридин (ЦТВ), циклопиазоновую кислоту (ЦПК) и ряд других.

Загрязненность зерна микотоксинами напрямую зависит от распространенности их продуцентов. На территории Российской Федерации наиболее часто встречаются фузариоз и альтернариоз злаков (14). Среди вторичных метаболитов микромицетов рода Fusarium в России в зерне регламентируют содержание ДОН, Т-2 токсина, ЗЕА, ФВ1 и ФВ2. К производным ДОН относятся его ацетильные производные, ниваленол (НИВ), фузаренон X (ФУЗХ), а также гликозиды и сульфопроизводные. Их основные 
продуценты $-F$. graminearum, $F$. culmorum и $F$. cerealis, причем в зависимости от географического положения региона доминирующими оказываются штаммы, преимущественно синтезирующие НИВ либо ДОН + 3-АщДОН или ДОН + 15-АџДОН, возможен смешанный хемотип (15-17). Изучение загрязненности зерна урожаев 2005-2010 годов показало, что в среднем по России степень контаминации ДОН гораздо ниже МДУ $(18,19)$, наиболее загрязнено зерно из Южного и Северо-Кавказского федеральных округов (20). Эти территории наряду с Дальневосточным федеральным округом традиционно считаются ареалами фузариоза зерновых в России $(17,21)$. В то же время вследствие изменения климата и обмена семенным материалом происходит постепенное продвижение более агрессивных патогенов на север: например, F. graminearum - продуцент ДОН и ЗЕА выявляют в зерне, выращенном на северо-западе России (22). С 2003 года в зернопроизводящих регионах Западной Европы также наблюдается вытеснение F. culmorum более теплолюбивым и токсиногенным видом $-F$. graminearum $(16,23)$.

В группу Т-2 токсина входят НТ-2 токсин, Т-2 триол, диацетоксискирпенол, НЕОС и их производные. Их основные продуценты - F. sporotrichioides, $F$. langsethiae и $F$. poae. Загрязнение этими микотоксинами особенно характерно для овса и ячменя (частота обнаружения до 75-95 \%), в меньшей степени - для пшеницы, тогда как для зерна кукурузы доля положительных образцов - менее 22 \% (24). Данные микологических исследований свидетельствуют о повсеместной распространенности продуцентов токсинов группы Т-2 в зерне из Краснодарского и Ставропольского краев (25), Центрального и Северо-Западного федеральных округов (26), в Зауралье (на примере Курганской, Свердловской, Тюменской, Челябинской областей) (27). В последней работе частота обнаружения Т-2 и НТ-2 токсинов в образцах овса, ячменя и пшеницы составила в среднем $59 \%$. Также были выявлены Т-2 триол и диацетоксискирпенол. Причем загрязненность производными Т-2 токсина оказалась более характерна для овса и ячменя, чем для пшеницы, что согласуется с данными из Хорватии (28) и результатами мониторинга отечественного продовольственного зерна урожаев 2008-2010 годов: частота обнаружения Т-2 и НТ-2 токсинов в зерне пшеницы варьировала в пределах 5-18 \%, ржи - 0-57 \%, ячменя - 21-27\%, овса - 13-50 \% (18).

3ЕА и его производные - это метаболиты F. graminearum, F. culmorum, F. cerealis, F. equiseti, F. crookwellense и F. semitectum (27). В России ЗЕА был выявлен в 7 \% образцов продовольственного зерна кукурузы, произведенного в 2000-2016 годах, при этом содержание токсина в образцах варьировало от 5 до 315 мкг/кг (29). Для пшеницы урожаев 2005-2010 годов контаминированные образцы составляли 2-8 \%, для ячменя - 0-39 \%, для овса $-12-67 \%(18)$.

$F$. verticillioides и $F$. proliferatum - основные продуценты ФВ преимущественно поражают кукурузу и сорго (13). Частота обнаружения ФВ1 в образцах кукурузы урожаев 2000-2016 годов в России превышала $85 \%$, а $\Phi B_{2}-50 \%$, при этом в $10 \%$ из 271 исследованного образца содержание ФВ превышало МДУ (30). Также есть сведения об обнаружении ФВ1 в фуражном зерне ячменя и пшеницы (31).

Вторичные метаболиты грибов Aspergillus и Penicillium - АФЛ и ОТА представляют самые высокие риски для здоровья человека. В рамках мониторинга микотоксинов в российском продовольственном зерне в 20132016 годах из 49 исследованных образцов кукурузы были выявлены три (6 \%), содержащие АФЛ В1, причем в двух образцах с превышением МДУ (30). Исследования продовольственного зерна пшеницы, ржи, ячменя и 
овса урожаев 2003 и 2004 годов показали, что соответственно 6\%, 34 \%, $16 \%$ и $8 \%$ образцов были контаминированы ОТА. МДУ ОТА был превышен в $2,5 \%$ из 272 исследованных проб (32). В образцах зерна урожаев 20122014 годов только два (1\%) содержали этот токсин (20).

Метаболиты Alternaria занимают второе место по распространенности в зерновых после фузариотоксинов (33). Они проявляют иммуномодулирующее действие, АОН и АМЭ обладают генотоксичностью (34). Повсеместная распространенность микромицетов Alternaria в зерновых в России была показана на примере образцов из республик Северного Кавказа (35), Ставропольского и Краснодарского краев, областей Центрального федерального округа (36), Урала (37). В образцах пшеницы, овса и ячменя из областей Уральского федерального округа выявлены ТЕ, тенуазоновая кислота, АОН и АМЭ.

Сведения о распространенности в отечественном зерне прочих микотоксинов крайне отрывочны. В образцах зерна пшеницы, ячменя и овса (всего 56 проб) из Зауралья детектировали монилиформин и боверицин (соответственно в 12,5 \% и 34,0 \% образцов) (27). Распространенность СТЦ (биогенный предшественник АФЛ В1) в российском продовольственном зерне и продуктах его переработки достигала $8 \%$, а уровень контаминации - 150 мкг/кг (38). По оценкам Европейского агентства по безопасности пищи (EFSA), содержание СТЦ в зерновых и продуктах их переработки не более 1,5-8,0 мкг/кг не представляет опасности (39). По сравнению с АФЛ В1 СТЦ менее токсичен, но гораздо более распространен: например, в пшенице из Китая его обнаруживали в шесть раз чаще, чем АФЛ В1 (40). Также представляет интерес определение в продовольственном зерне малоизученных микотоксинов ЦИТ, ЦПК и МФК. ЦИТ и ОТА часто выявляют совместно, оба микотоксина нефротоксичны, возможно проявление их синергетического эффекта. Ранее была показана высокая частота совместного выявления ЦИТ и ОТА в кормах (41), данные о контаминации продовольственного зерна в литературе отсутствуют. МФК - частый контаминант растительного сырья, ее содержание может достигать нескольких миллиграммов на килограмм. Не обладая выраженными токсическими свойствами, МФК в больших концентрациях проявляет свойства иммуносупрессора (42). ЦПК цитотоксична, способна подавлять иммунную систему; ее часто обнаруживают в сочетаниях с АФЛ (43).

Одновременное определение в зерне регламентируемых микотоксинов, их производных, вторичных метаболитов Alternaria и малоизученных вторичных метаболитов микромицетов позволяет оценить его соответствие действующим нормам безопасности, получить информацию о совместной контаминации образца различными группами микотоксинов, ретроспективно охарактеризовать вероятных продуцентов. Накопление и анализ таких сведений позволит, с одной стороны, полнее оценить риски для здоровья человека, связанные с совместной контаминацией зерна регламентируемыми и нерегламентируемыми микотоксинами, с другой - выявить потенциальные угрозы, обусловленные изменением профиля продуцентов.

В настоящей работе мы впервые представляем данные о загрязненности 28 микотоксинами продовольственного зерна из Центрального, Южного, Приволжского, Уральского, Сибирского, Северо-Кавказского и Дальневосточного федеральных округов (всего из 21 субъекта) по пяти культурам (пшеница, кукуруза, ячмень, овес и рожь). Аналиты включали группу афлатоксинов (АФЛ В1, В $2, \mathrm{G}_{1}, \mathrm{G}_{2}$ и СТЦ); ОТА; фузариотоксины ДОН и его группу (3- и 15-АцДОН, НИВ, ФУЗ Х), Т-2 токсин и его группу (НТ-2 токсин, Т-2 триол, НЕОС), ЗЕА и его группу ( $\alpha-$ и $\beta$-ЗЕЛ), ФВ 1 и ФВ 
микотоксины Alternaria (ТЕ, АЛТ, АОН, АМЭ); а также МФК, ЦПК, ЦИТ и ЦТВ. Впервые представлены систематические данные о контаминации продовольственного зерна России 3- и 15-АщДОН, НИВ, ФУЗ Х, Т-2 триолом, НЕОС, $\alpha-$ и $\beta$-ЗЕЛ, ТЕ, АЛТ, АОН, АМЭ, а также МФК, ЦПК, ЦИТ и ЦТВ. ЦТВ в продовольственном зерне пшеницы, ячменя и кукурузы нами обнаружен впервые.

Настоящее исследование посвящено анализу загрязненности основных видов продовольственного зерна из регионов России регламентируемыми микотоксинами, их структурными производными, вторичными метаболитами Alternaria, некоторыми другими малоизученными микотоксинами.

Методика. Пробы продовольственного зерна урожая 2018 года (всего 162 образца) были предоставлены для исследования филиалами краевых и областных Центров гигиены и эпидемиологии Федеральной службы по надзору в сфере защиты прав потребителей и благополучия человека Центрального (Тульская, Тамбовская, Курская, Воронежская, Липецкая, Белгородская и Орловская области), Южного (Краснодарский край и Ростовская область), Приволжского (Пензенская, Саратовская, Оренбургская, Самарская области и Республика Татарстан), Уральского (Тюменская и Челябинская области), Сибирского (Новосибирская, Омская области и Алтайский край), Северо-Кавказского (Ставропольский край) и Дальневосточного (Амурская область) федеральных округов России. Образцы отбирали по ГОСТ P ISO 24333-2011 («Зерно и продукты его переработки. Отбор проб». М., 2013) от однородных партий, хранящихся на хлебоприемных и перерабатывающих предприятиях. Проанализировано 114 проб зерна пшеницы, 18 - ячменя, 14 - кукурузы, 8 - овса, 8 - ржи.

Микотоксины определяли методом ВЭЖХ-МС/МС с использованием хроматографической системы Agilent 1100 и масс-спектрометрического детектора с тройным квадруполем Agilent TQ 6410 («Agilent Technologies», США) в условиях положительной электрораспылительной ионизации при атмосферном давлении в режиме мониторинга множественных реакций (MRM). Напряжение на капилляре источника ионов детектора составляло $4000 \mathrm{~B}$, температура источника - $100{ }^{\circ} \mathrm{C}$, температура газа осушителя (азот) - $350{ }^{\circ} \mathrm{C}$; давление небулайзера - 60 psi (4,14 Бар). Хроматографическое разделение осуществляли на колонке Zorbax SB-C18 (150×4,6 мм, диаметр частиц сорбента 3,5 мкм), термостатированной при $25^{\circ} \mathrm{C}$, в режиме градиентного элюирования. Подвижная фаза А - вода:ацетонитрил (95:5), Б - ацетонитрил. Обе фазы подкислены муравьиной кислотой $(0,1$ об.\%). Схема градиента: старт - $0 \%$ Б, далее линейный рост до $95 \%$ Б в течение 30 мин, $95 \%$ Б до 36 мин, линейное снижение до $0 \%$ Б за 1 мин и уравновешивание колонки в течение 6 мин. Общее время хроматографирования - 43 мин, объем вносимой пробы - 20 мкл. Каждую пробу хроматографировали дважды. Аналиты идентифицировали по совпадению времени удерживания, регистрации характерных ионов-продуктов и соотношению интенсивности их сигналов. Количественный расчет проводили методом внешней калибровки. Для анализа проб зерна пшеницы строили калибровку «на растворителе», для учета влияния матрицы на аналитический сигнал Т-2 триола, НТ-2 и Т-2 токсинов использовали изотопномеченые внутренние стандарты - $\left[{ }^{13} \mathrm{C}_{22}\right]-\mathrm{HT}-2$ для НТ-2 токсина и $\left[{ }^{13} \mathrm{C}_{24}\right]-\mathrm{T}-2$ для T-2 триола и T-2 токсина. Количественное определение микотоксинов в зерне кукурузы, ячменя, ржи и овса проводили методом внешней калибровки «на чистой матрице». Для построения калибровочной зависимости использовали серию из восьми многокомпонентных стандартных растворов. При приготовлении стандартов «на растворителе» к 50 мкл 
стандартного раствора добавляли 50 мкл экстрагента, 100 мкл подвижной фазы А и 10 мкл смеси внутренних стандартов. При приготовлении стандартных растворов «на матрице» к 50 мкл стандартного раствора добавляли 50 мкл экстракта «чистой» матрицы и 100 мкл подвижной фазы А. ПО и ПКО рассчитаны по $3 \mathrm{~S} / \mathrm{N}$ - и $7 \mathrm{~S} / \mathrm{N}$ критериям соответственно, где $\mathrm{S} / \mathrm{N}-$ соотношение сигнал/шум.

Пробы готовили в соответствии с МВИ 410/4-2020 «Метод мультидетекции микотоксинов в зерне и первичных продуктах его переработки» (утвержден Роспотребнадзором). Для этого 100 г отобранной пробы измельчали в лабораторной мельнице до однородного состояния. В центрифужную пробирку объемом 50 мл помещали 5,0 г однородного измельченного образца, добавляли 25 мл смеси ацетонитрил:вода (80:20 об.\%), подкисленной муравьиной кислотой $(0,5$ об.\%). Экстракцию проводили в течение 30 мин попеременно на шейкере (дважды по 10 мин) и в ультразвуковой ванне (10 мин). Полученный экстракт фильтровали, отбирали 200 мкл и разбавляли 600 мкл подвижной фазы А, центрифугировали при скорости не менее 4000 об/мин, при необходимости обезжиривали гексаном, 200 мкл разбавленного экстракта переносили в хроматографическую виалу, вносили 10 мкл смеси внутренних стандартов ([$\left.{ }^{13} \mathrm{C}_{24}\right]-\mathrm{T}-2$ и $\left.\left[{ }^{13} \mathrm{C}_{22}\right]-\mathrm{HT}-2\right)$ (для проб пшеницы). Анализ проводили в двух повторностях.

Результаты. Параметры MRM, время удерживания аналитов, степени извлечения (средние значения для исследованных культур), пределы обнаружения (ПО) и количественного определения (ПКО) микотоксинов приведены в таблице 1. Для количественного определения использовали первый из указанных в таблице 1 переход материнский ион-дочерний ион.

Контаминация зерна пшеницы. В пшенице из разных регионов России чаще других выявляли ДОН, Т-2 и НТ-2 токсины, токсины Alternaria (АОН, АМЭ и ТЕ), ОТА, ЦИТ, МФК и ЗЕА (табл. 2). Ацетильные производные ДОН (3- и 15-АџДОН) обнаружили только в двух образцах пшеницы из Амурской области. В единичных случаях детектировали СТЦ (1,3 мкг/кг, образец из Липецкой области), $\beta$-ЗЕЛ (366 мкг/кг, образец из Амурской области) и ЦТВ (56 мкг/кг, образец из Краснодарского края). НИВ, ФУЗХ, НЕОС, Т-2 триол, АФЛ, ФВ, АЛТ, $\alpha$-ЗЕЛ и ЦПК выявлены не были.

Основными контаминантами зерна пшеницы из Центрального, Приволжского и Уральского федеральных округов оказались микотоксины $\mathrm{Al}$ ternaria, среди которых доминировал ТЕ. Он был выявлен в 62-88 \% проб. Эти данные хорошо согласуются с результатами, полученными А.С. Ориной с соавт. $(37,44)$ для пшеницы урожаев 2017 и 2018 годов из Уральского федерального округа: ТЕ (от 2,9 до 79,9 мкг/кг) был обнаружен во всех 36 исследованных образцах. Токсинами Т-2 + НТ-2 и ДОН были загрязнены соответственно не более $7 \%$ и $11 \%$ из изученных нами проб. Ни в одной из проб содержание регламентируемых микотоксинов не превышало МДУ.

В пшенице из Сибирского федерального округа также превалировал TЕ (91 \%). В 20 \% проб мы обнаружили Т-2 + НТ-2 и ДОН; содержание регламентируемых микотоксинов, за исключением ОТА, было значительно ниже МДУ. ОТА выявили в 4 из 11 исследованных образцов (36 \%), причем в одном с превышением МДУ более чем в 4 раза. В среднем по всем регионам частота обнаружения ОТА в пшенице составила 6 \% (7 образцов). Интересно, что для трех из них было зафиксировано совместное присутствие ОТА и ЦИТ (один образец из Краснодарского края и два - из Омской области). Высокую частоту совместной контаминации пшеницы ОТА и ЦИТ ранее отмечали для фуражного зерна из центральных регионов европейской части России: 16 из 30 контаминированных ОТА образцов содержали ЦИТ (41). 
1. Параметры детектирования микотоксинов и их характеристики при анализе образцов продовольственного зерна методом высокоэффективной жидкостной хроматографии с тандемной масс-спектрометрией (хроматографическая система Agilent 1100, масс-спектрометрический детектор Agilent TQ 6410, «Agilent Technologies», США)

\begin{tabular}{|c|c|c|c|c|c|c|c|c|c|}
\hline Аналит & tR, МИН & Материнский & ион, $\mathrm{m} / \mathrm{z}$ & Дочерние ионы, m/z & $\mathrm{F}, \mathrm{B}$ & CE, B & Степень извлечения, \% & ПО, МКг $/ \mathrm{K} \Gamma$ & ПКО, мКг/КГ \\
\hline $\begin{array}{l}\text { НИВ } \\
\end{array}$ & 10,1 & {$[\mathrm{M}+\mathrm{Na}]^{+}$} & 313,3 & 175,$3 ; 247,2$ & 90 & $10 ; 2$ & 85,1 & 100 & 200 \\
\hline ДОН & 12,0 & {$[\mathrm{M}+\mathrm{H}]^{+}$} & 297,1 & 249,$2 ; 203,1 ; 175,2$ & 90 & $5 ; 10 ; 18$ & 98,7 & 20 & 40 \\
\hline ФУЗХ & 13,8 & {$[\mathrm{M}+\mathrm{H}]^{+}$} & 355,2 & $175 ; 247$ & 100 & $20 ; 4$ & 116,3 & 20 & 40 \\
\hline HEOC & 14,0 & {$[\mathrm{M}+\mathrm{H}]^{+}$} & 383,2 & 305,$1 ; 185,1$ & 116 & $2 ; 14$ & 88,3 & 0,3 & 1 \\
\hline 15-АшДОН & 16,2 & {$[\mathrm{M}+\mathrm{H}]^{+}$} & 339,3 & 261,$3 ; 231,1$ & 90 & $5 ; 5$ & 107,2 & 20 & 40 \\
\hline 3-АшДОН & 16,6 & {$[\mathrm{M}+\mathrm{H}]^{+}$} & 339,3 & 231,$1 ; 212,8 ; 261,3$ & 90 & $5 ; 8 ; 5$ & 97,9 & 10 & 20 \\
\hline$\Phi B_{1}$ & 17,6 & {$[\mathrm{M}+\mathrm{H}]^{+}$} & 722,4 & 334,$2 ; 352,5 ; 316,4$ & 165 & $40 ; 40 ; 40$ & 89,9 & 5 & 20 \\
\hline Т-2 триол & 18,1 & {$[\mathrm{M}+\mathrm{H}]^{+}$} & 405,2 & 303,$0 ; 124,8$ & 100 & $12 ; 12$ & 94,4 & 30 & 80 \\
\hline АФЛ $\mathrm{G}_{2}$ & 18,5 & {$[\mathrm{M}+\mathrm{H}]^{+}$} & 331,1 & 245,$2 ; 257,2$ & 150 & $30 ; 30$ & 90,7 & 1 & 2,5 \\
\hline ФВ2 & 18,6 & {$[\mathrm{M}+\mathrm{H}]^{+}$} & 706,5 & 336,$0 ; 354,0 ; 318$ & 165 & $35 ; 30 ; 38$ & 94,9 & 5 & 10 \\
\hline АЛТ & 18,8 & {$[\mathrm{M}+\mathrm{H}]^{+}$} & 293,1 & 257,$1 ; 239,1$ & 45 & $8 ; 16$ & 114,6 & 2 & 5 \\
\hline АФЛ $\mathrm{G}_{1}$ & 19,5 & {$[\mathrm{M}+\mathrm{H}]^{+}$} & 329,1 & 243,$2 ; 200,0 ; 283,0$ & 135 & $25 ; 46 ; 20$ & 92,9 & 0,5 & 1 \\
\hline АФЛ В2 & 19,5 & {$[\mathrm{M}+\mathrm{H}]^{+}$} & 315,3 & 287,$0 ; 259,1 ; 231,2$ & 135 & $22 ; 30 ; 30$ & 92,4 & 0,5 & 1 \\
\hline АФЛ $\mathrm{B}_{1}$ & 20,5 & {$[\mathrm{M}+\mathrm{H}]^{+}$} & 313,2 & 128,$0 ; 241,1 ; 285,2$ & 135 & $80 ; 35 ; 20$ & 94,3 & 0,5 & 1 \\
\hline HT-2 & 20,6 & {$[\mathrm{M}+\mathrm{Na}]^{+}$} & 447,3 & 345,$2 ; 285,2$ & 190 & $16 ; 16$ & 90,3 & 2 & 5 \\
\hline$\left[{ }^{13} \mathrm{C}_{22}\right]-\mathrm{HT}-2$ & 20,6 & {$[\mathrm{M}+\mathrm{Na}]^{+}$} & 469,2 & 362,0 & 150 & 30 & - & - & - \\
\hline $\mathrm{AOH}$ & 21,1 & {$[\mathrm{M}+\mathrm{H}]^{+}$} & 259,1 & 128,$0 ; 185,1$ & 153 & $40 ; 30$ & 110,7 & 2 & 5 \\
\hline TE & 21,1 & {$[\mathrm{M}+\mathrm{H}]^{+}$} & 415,2 & 132,$0 ; 312,2$ & 107 & $42 ; 8$ & 113,6 & 0,5 & 1 \\
\hline$\alpha$-ЗЕЛ & 22,4 & {$[\mathrm{M}+\mathrm{H}]^{+}$} & 303,2 & 285,$2 ; 267,0$ & 110 & $5 ; 10$ & 109,2 & 4 & 10 \\
\hline МФК & 23,6 & {$[\mathrm{M}+\mathrm{H}]^{+}$} & 321,1 & 303,$2 ; 207,1$ & 73 & $4 ; 16$ & 101,5 & 4 & 10 \\
\hline$\beta$-ЗЕЛ & 24,0 & {$[\mathrm{M}+\mathrm{H}]^{+}$} & 303,2 & 285,$2 ; 267,0$ & 110 & $5 ; 10$ & 118,3 & 4 & 10 \\
\hline ЦТВ & 24,1 & {$[\mathrm{M}+\mathrm{H}]^{+}$} & 403,2 & 285,$0 ; 297,0$ & 45 & $10 ; 10$ & 94,7 & 4 & 10 \\
\hline ЦИТ & 24,8 & {$[\mathrm{M}+\mathrm{H}]^{+}$} & 251,2 & 233,$1 ; 205,0 ; 115,2$ & 93 & $16 ; 24 ; 52$ & 91,5 & 2 & 3 \\
\hline $\mathrm{T}-2$ & 24,8 & {$[\mathrm{M}+\mathrm{Na}]^{+}$} & 489,3 & 245,$1 ; 387,1 ; 327,2$ & 165 & $24 ; 17 ; 20$ & 99,2 & 0,5 & 2 \\
\hline$\left[{ }^{13} \mathrm{C}_{24}\right]-\mathrm{T}-2$ & 24,8 & {$[\mathrm{M}+\mathrm{Na}]^{+}$} & 513,5 & 344,2 & 190 & 20 & - & - & - \\
\hline OTA & 25,5 & {$[\mathrm{M}+\mathrm{H}]^{+}$} & 404,2 & 239,$1 ; 358,2 ; 221,0$ & 105 & $20 ; 10 ; 34$ & 96,1 & 0,5 & 1 \\
\hline 3EA & 26,8 & {$[\mathrm{M}+\mathrm{H}]^{+}$} & 319,2 & 185,$0 ; 283,2 ; 301,2$ & 90 & $22 ; 5 ; 5$ & 104,6 & 2 & 5 \\
\hline АМЭ & 26,8 & {$[\mathrm{M}+\mathrm{H}]^{+}$} & 273,1 & 258,$0 ; 230,0$ & 156 & $24 ; 30$ & 108,6 & 2 & 5 \\
\hline
\end{tabular}


СТЦ

28,2

${ }^{[\mathrm{M}+\mathrm{H}]^{+}}$

196,$1 ; 182,1$

$\begin{array}{r}120 \\ 45\end{array} 35 ; 22$

82,8

1

Продолжение таблицы 1

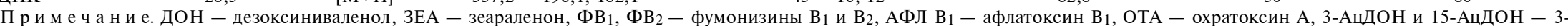

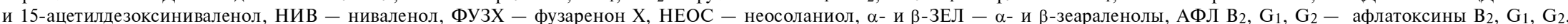

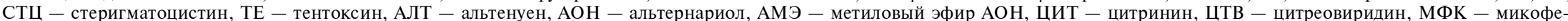

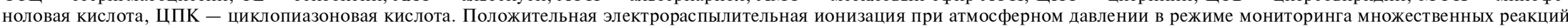

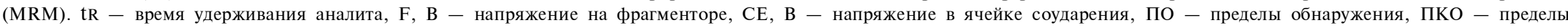

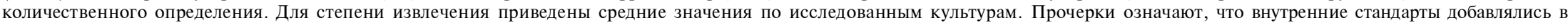
подготовленную пробу перед анализом.

2. Частота обнаружения и содержание микотоксинов в исследованных образцах продовольственного зерна пшеницы урожая 2018 года из разных регионов России ( $n=114$; по результатам ВЭЖХ/MC-MC)

\begin{tabular}{|c|c|c|c|c|c|c|c|c|c|c|c|}
\hline \multirow{2}{*}{ Регион } & \multirow{2}{*}{$\begin{array}{l}\text { Контаминирова- } \\
\text { но/всего, шт. (\%) }\end{array}$} & \multicolumn{10}{|c|}{ Содержание (min-max; среднее), мкг/кг (доля контаминированных проб, \%) } \\
\hline & & ДОН & 3EA & $\mathrm{T}-2$ & HT-2 & OTA & ЦИТ & $\mathrm{AOH}$ & АМЭ & TE & МФК \\
\hline ЦФО & $\begin{array}{l}19 / 29 \\
(66 \%)\end{array}$ & $\begin{array}{c}100 \\
(3 \%)\end{array}$ & $\begin{array}{c}10 \\
(3 \%)\end{array}$ & $\begin{array}{l}4 \text { и } 17 \\
(7 \%)\end{array}$ & $\begin{array}{c}35 \text { и } 45 \\
(7 \%)\end{array}$ & $\begin{array}{c}0,4 \\
(3 \%)\end{array}$ & - & $\begin{array}{c}<\text { ПКО-13; } 11 \\
(21 \%)\end{array}$ & $\begin{array}{c}<\text { ПКО-10;6 } \\
(21 \%)\end{array}$ & $\begin{array}{l}2-37 ; 9 \\
(62 \%)\end{array}$ & $\begin{array}{c}40 \\
(3 \%)\end{array}$ \\
\hline ПривФО & $\begin{array}{l}16 / 19 \\
(84 \%)\end{array}$ & $\begin{array}{c}120 \text { и } 370 \\
(11 \%)\end{array}$ & $\begin{array}{c}16 \\
(5 \%)\end{array}$ & $\begin{array}{c}15 \\
(5 \%)\end{array}$ & $\begin{array}{l}5 \text { и } 45 \\
(11 \%)\end{array}$ & - & - & $\begin{array}{c}<\prod_{(16 \%)} \%-10 \\
\text { (16 }\end{array}$ & $\begin{array}{c}\text { ПКО-21 } \\
(21 \%)\end{array}$ & $\begin{array}{l}1-90 ; 11 \\
(74 \%)\end{array}$ & $\begin{array}{l}3700 \\
(5 \%)\end{array}$ \\
\hline УралФО & $\begin{array}{c}7 / 8 \\
(88 \%)\end{array}$ & - & - & - & - & $\begin{array}{c}2,9 \\
(13 \%)\end{array}$ & - & - & - & $\begin{array}{l}5-49 ; 14 \\
(88 \%)\end{array}$ & $\begin{array}{l}3500 \\
(13 \%)\end{array}$ \\
\hline СибФО & $\begin{array}{l}10 / 11 \\
(91 \%)\end{array}$ & $\begin{array}{c}180 \text { и } 250 \\
(18 \%)\end{array}$ & - & $\begin{array}{c}2 \text { и } 3 \\
(18 \%)\end{array}$ & $\begin{array}{l}5-70 ; 34 \\
(27 \%)\end{array}$ & $\begin{array}{c}0,8-22 ; 7,8 \\
(36 \%)\end{array}$ & $\begin{array}{l}15 \text { и } 97 \\
(18 \%)\end{array}$ & $\begin{array}{c}<\text { ПКО } \\
(9 \%)\end{array}$ & - & $\begin{array}{c}6-83 ; 27 \\
(91 \%)\end{array}$ & $\begin{array}{l}380 \\
(9 \%)\end{array}$ \\
\hline $\begin{array}{l}\text { Амурская область } \\
\text { (ДВФО) }\end{array}$ & $\begin{array}{c}3 / 3 \\
(100 \%)\end{array}$ & $\begin{array}{c}430 \text { и } 530 \\
(67 \%)\end{array}$ & - & $\begin{array}{c}5 \\
(33 \%)\end{array}$ & $\begin{array}{c}13 \\
(33 \%)\end{array}$ & - & - & $\begin{array}{c}26 \\
(33 \%)\end{array}$ & $\begin{array}{l}<\Pi K O \\
(33 \%)\end{array}$ & $\begin{array}{l}5-90 ; 38 \\
(100 \%)\end{array}$ & - \\
\hline $\begin{array}{l}\text { Краснодарский край } \\
\text { (ЮФО) }\end{array}$ & $\begin{array}{l}8 / 15 \\
(53 \%)\end{array}$ & $\begin{array}{c}120-1270 ; 500 \\
(53 \%)\end{array}$ & $\begin{array}{c}5 \\
(7 \%)\end{array}$ & - & $\begin{array}{c}5 \text { и } 8 \\
(13 \%)\end{array}$ & $\begin{array}{c}9 \\
(7 \%)\end{array}$ & $\begin{array}{l}118 \\
(7 \%)\end{array}$ & - & - & $\begin{array}{l}5 \text { и } 6 \\
(13 \%)\end{array}$ & - \\
\hline $\begin{array}{l}\text { Ростовская область } \\
\text { (ЮФО) }\end{array}$ & $\begin{array}{l}1 / 8 \\
(13 \%)\end{array}$ & - & - & - & - & - & $\begin{array}{c}2,5 \\
(13 \%)\end{array}$ & - & - & - & - \\
\hline $\begin{array}{l}\text { Ставропольский край } \\
\text { (СКФО) }\end{array}$ & $\begin{array}{c}6 / 21 \\
(29 \%)\end{array}$ & $\begin{array}{c}100 \text { и } 730 \\
(10 \%)\end{array}$ & - & - & - & - & - & - & $\begin{aligned}< & \prod_{(14 \%)} \%-20\end{aligned}$ & $\begin{array}{c}7-197 ; 72 \\
(14 \%)\end{array}$ & - \\
\hline
\end{tabular}


Еще одной особенностью контаминации микотоксинами пшеницы из Центрального, Приволжского, Уральского и Сибирского федеральных округов оказалось выявление МФК. Частота ее обнаружения составляла 3$13 \%$, диапазон содержания в положительных образцах - 40-3700 мкг/кг, что отчасти согласуется данными литературы о контаминации этим микотоксином фуражного зерна пшеницы (встречаемость МФК < 6 \%, содержание в пределах 63-1255 мкг/кг) (45). В образцах пшеницы из других регионов этот микотоксин обнаружен не был. Обращают на себя внимание выявленные нами случаи высокого накопления МФК в исследованных образцах продовольственного зерна: 3500 мкг/кг и 3700 мкг/кг в пшенице соответственно из Тюменской и Саратовской областей. Ранее сообщалось, что при нарушении условий хранения, приведших к самосогреванию, содержание МФК в семенах подсолнечника возросло с 53 мкг/кг до 2630 мкг/кг (46). МФК не обладает выраженными токсическими свойствами, но как сильный иммунодепрессант широко применяется в трансплантологии. Стандартная суточная терапевтическая доза МФК составляет около 1,5 г (47), что на два порядка ниже ее содержания в килограмме наиболее контаминированного из исследованных образцов зерна пшеницы. Однако с учетом распространенности МФК в пищевых продуктах массового потребления, представленных на рынке России $(48,49)$, возможность хронического поступления этого микотоксина с пищей вызывает озабоченность.

Пшеница из основных зернопроизводящих регионов России - Южного и Северо-Кавказского федеральных округов была контаминирована микотоксинами Alternaria в меньшей степени, чем образцы из Центрального, Приволжского, Уральского и Сибирского федеральных округов. В зерне из Ростовской области альтернариатоксины не были обнаружены. В 13 \% образцов из Краснодарского края выявили только один из них - TE, распространенность которого в пшенице из других регионов достигала $100 \%$. В трех из 21 исследованного образца (частота обнаружения $14 \%$ ) из Ставропольского края был детектирован ТЕ, в других трех - АМЭ (14 \%). АОН в пшенице из Южного и Северо-Кавказского федеральных округов мы не выявили. Согласно данным литературы, совместное присутствие микромицетов Alternaria и Fusarium может подавлять синтез АОН (50). Действительно, основным контаминантом пшеницы из этих регионов традиционно является фузариотоксин ДОН. В образцах из Краснодарского края частота его обнаружения составила 40 \%, в двух случаях содержание токсина превысило МДУ. В одном из образцов наряду с ДОН выявили ЗЕА, ОТА и ЦИТ, причем содержание ОТА было практически в 2 раза выше МДУ. Только для $10 \%$ проб пшеницы из Ставропольского края были загрязнены ДОН, все на уровне ниже МДУ. Ацетильные производные ДОН в исследованных образцах из Южного и Северо-Кавказского федеральных округов не детектировались. Наименее контаминированной оказалась пшеница из Ростовской области (Южный федеральный округ): только в одном образце был обнаружен ЦИТ.

Данные о загрязнении пшеницы микотоксинами в мире значительно разнятся. Следует отметить, что по сравнению с другими ведущими экспортерами зерна в России пшеница в среднем в меньшей степени контаминирована ДОН (51). В странах ЕС частота обнаружения этого микотоксина в пшенице урожаев 2005-2012 годов, по данным J. Alexander с соавт. (10), варьировала в диапазоне от 60 до $100 \%$, а максимальное содержание достигало 4130 мкг/кг. В пшенице твердых сортов из Италии $(n=74)$ ДОН выявили в $16 \%$ образцов при содержании 48-2267 мкг/кг, Т-2 и НТ-2 токсины - в $8 \%$ образцов (10-149 мкг/кг), АОН - в $31 \%$ образцов (8-121 мкг/кг), АМЭ - в $26 \%$ (9-48 мкг/кг) (52). Содержание АОН и АМЭ в озимой 
пшенице из Германии (урожаи 2001-2010 годов) достигало 832 мкг/кг (частота обнаружения 0-77 \%) и 905 мкг/кг (частота обнаружения 0-33 \%) (53).

Контаминация зерна кукурузы. Содержание микотоксинов было исследовано в 14 образцах зерна кукурузы (табл. 3): 11 проб поступили из Южного и Северо-Кавказского федеральных округов, две - из Центрального, одна - из Приволжского. Последние три образца были контаминированы незначительно, уровни контаминации - ФВ1 (40 мкг/кг) + НТ-2 (7 мкг/кг) и ФВ1 (220 мкг/Кг) - были в десятки раз ниже МДУ. В образцах из Южного и Северо-Кавказского федеральных округов основными контаминантами были ФВ1 или ФВ $1+$ ФВ $_{2}$, а также ДОН или ДОН + 15-АщДОН; примерно в трети образцов были выявлены МФК и НЕОС; два из 11 образцов были контаминированы совместно Т-2 и НТ-2 токсинами. Частота обнаружения микотоксинов в порядке ее убывания была следующей: ФВ (с превалированием ФВ 1 ) > ДОН и 15-АцДОН > НЕОС, МФК > Т-2 и НТ-2 токсины > ЗЕА, ОТА, ЦИТ, ЦТВ.

ФВ - основные контаминанты зерна кукурузы в России (30). По содержанию ФВ все изученные пробы соответствовали требованиям регламента. В одном образце из Краснодарского края было превышено содержание ОТА (13 мкг/кг). Относительно высокая частота выявления НЕОС в кукурузе согласуется с данными из Испании (54), в то время как в образцах из Африки, Японии (55) и Бразилии (56) НЕОС не обнаруживали. Основные трихотецены группы А - Т-2 и НТ-2 токсины детектировали в $18 \%$ исследованных образцов. Для сравнения: в зерне кукурузы из Хорватии $(n=71)$ эти токсины обнаруживали с частотой $27 \%$, суммарное содержание варьировало от 15 до 332 мкг/кг (28). Есть сведения о частом обнаружении (наряду с ФВ и ДОН) Т-2 токсина в отечественном фуражном зерне кукурузы $(57,58)$. В пробах кукурузы мы не выявили метаболитов Alternaria, что может быть связано с низкой подверженностью зерна кукурузы заражению этими микромицетами вследствие специфичного строения початка (36). То же в целом подтверждают данные литературы. Например, менее $7 \%$ образцов продовольственного зерна кукурузы из южной части Бразилии были контаминированы АОН, AME, TE (56), в образцах из Сербии средняя частота обнаружения АОН и ТЕ также не превышала $10 \%$, в то время как для АМЕ и тенуазоновой кислоты она составила соответственно 40 и 35 \% (59). В фуражном зерне кукурузы из Центрального федерального округа, исследованном Г.П. Кононенко с соавт. (57), АОН детектировали с частотой $13,3 \%$.

Контаминация зерна ячменя, овса и ржи. В этих образцах микотоксикологический анализ также выявил зависимость набора обнаруженных контаминантов зерна от региона произрастания культуры (см. табл. 3). Число исследованных образцов у указанных видов было меньше, чем для пшеницы и кукурузы, поэтому выводы о распространенности микотоксинов в ячмене, овсе и ржи из различных регионов мы рассматривали как ориентировочные. Тем не менее полученные результаты хорошо согласуются друг с другом. Основными контаминантами зерна в Центральном, Приволжском, Уральском и Сибирском федеральных округах оказались Т2 и НТ-2 токсины (частота обнаружения - 20-50 \%) и вторичные метаболиты Alternaria, в первую очередь ТЕ (частота обнаружения - 33-100 \%). Среди альтернариатоксинов в образце ячменя из Алтайского края был обнаружен АЛТ в количестве 15 мкг/кг (единственный случай детектирования этого токсина в исследованных образцах зерна). Преимущественная контаминация зерна овса Т-2 и НТ-2 токсинами в сочетании микотоксинами $\mathrm{Al}$ ternaria соответствует данным о его зараженности их продуцентами (60). 
3. Частота обнаружения и содержание микотоксинов в исследованных образцах продовольственного зерна кукурузы, ячменя, ржи и овса урожая 2018 года из разных регионов России (по результатам ВЭЖХ/МС-МС)

\begin{tabular}{|c|c|c|c|c|c|c|c|c|c|c|c|c|c|c|c|c|}
\hline \multirow[b]{2}{*}{ Регион } & \multirow{2}{*}{\begin{tabular}{|l|} 
Контамини- \\
ровано/все- \\
го, шт. (\%)
\end{tabular}} & \multicolumn{15}{|c|}{ Содержание (min-max; среднее), мкг/кг (доля контаминированных проб, \%) } \\
\hline & & ДОН & $\begin{array}{l}15-А ц \\
\text { ДОН }\end{array}$ & 3EA & $\mathrm{T}-2$ & HT-2 & HEOC & OTA & ЦИТ & $\Phi B_{1}$ & $\Phi \mathrm{B}_{2}$ & $\mathrm{AOH}$ & АМЭ & TE & ЦТВ & МФК \\
\hline \multicolumn{17}{|c|}{ К у к у р у з а $(n=14)$} \\
\hline ЮФО + СКФО & $\begin{array}{c}11 / 11 \\
(100 \%)\end{array}$ & $\begin{array}{l}50-950 ; 407 \\
\quad(55 \%)\end{array}$ & $\begin{array}{c}14-36 ; 25 \\
(27 \%)\end{array}$ & $\begin{array}{c}34 \\
(9 \%)\end{array}$ & $\begin{array}{l}25 \text { и } 67 \\
(18 \%)\end{array}$ & $\begin{array}{c}41 \text { и } 194 \\
(18 \%)\end{array}$ & $\begin{array}{l}1-21 ; 6 \\
(27 \%)\end{array}$ & $\begin{array}{l}13 \\
(9 \%)\end{array}$ & $\begin{array}{c}6 \\
(9 \%)\end{array}$ & $\begin{array}{c}30-1560 ; 370 \\
(91 \%)\end{array}$ & $\begin{array}{c}40-170 ; 97 \\
(27 \%)\end{array}$ & - & - & - & $\begin{array}{c}57 \\
(9 \%)\end{array}$ & $\begin{array}{c}10-95 ; 35 \\
(27 \%)\end{array}$ \\
\hline ЦФО + ПривФО & $\begin{array}{c}2 / 3 \\
(66 \%)\end{array}$ & - & - & - & - & $\begin{array}{c}7 \\
(33 \%)\end{array}$ & & - & - & $\begin{array}{c}40 \text { и } 220 \\
(66 \%)\end{array}$ & - & - & - & - & - & - \\
\hline \multicolumn{17}{|c|}{ Я ч м ень $(n=17)$} \\
\hline ЦФО & $\begin{array}{c}6 / 6 \\
(100 \%)\end{array}$ & - & - & - & $\begin{array}{l}2-7 ; 4 \\
(50 \%)\end{array}$ & $\begin{array}{l}5-10 ; 8 \\
(50 \%)\end{array}$ & - & - & - & - & - & $\begin{array}{c}<\text { ПКО-135; } \\
72(67 \%)\end{array}$ & - & $\begin{array}{c}<\text { ПКО-5; }<\text { ПКО } \\
(67 \%)\end{array}$ & - & - \\
\hline $\begin{array}{l}\text { ПривФО + УралФО + } \\
\text { СибФО }\end{array}$ & $\begin{array}{c}5 / 5 \\
(100 \%)\end{array}$ & - & - & - & $\begin{array}{c}6 \\
(20 \%)\end{array}$ & - & - & - & $\begin{array}{c}2 \\
(20 \%)\end{array}$ & - & - & - & - & $\begin{array}{c}<\underset{(60 \%)}{\text { ПКО-23; } 11} \\
\text { (60) }\end{array}$ & - & - \\
\hline ЮФО + СКФО & $\begin{array}{c}6 / 6 \\
(100 \%)\end{array}$ & - & - & - & $\begin{array}{c}2 \\
(17 \%)\end{array}$ & $\begin{array}{l}5-34 ; 15 \\
(50 \%)\end{array}$ & $\begin{array}{l}- \\
\mathrm{Po} \text { ж }\end{array}$ & $\begin{array}{c}11 \\
(17 \%) \\
\text { b } \quad(n=\end{array}$ & $=8)^{-}$ & $\begin{array}{c}<\underset{(33 \%)}{\text { ПКО и } 20} \\
(33 \%)\end{array}$ & - & $\begin{array}{c}24 \\
(17 \%)\end{array}$ & $\begin{array}{c}5 \\
(17 \%)\end{array}$ & $\begin{array}{c}5 \\
(17 \%)\end{array}$ & $\begin{array}{c}10 \\
(17 \%)\end{array}$ & - \\
\hline ЦФО & $\begin{array}{c}2 / 3 \\
(66 \%)\end{array}$ & - & - & - & $\begin{array}{c}2 \\
(33 \%)\end{array}$ & $\begin{array}{c}6 \\
(33 \%)\end{array}$ & - & - & - & - & - & $\begin{array}{c}5 \\
(33 \%)\end{array}$ & $\begin{array}{c}<\text { ПКО } \\
(33 \%)\end{array}$ & $\begin{array}{l}8 \text { и } 15 \\
(66 \%)\end{array}$ & - & - \\
\hline $\begin{array}{l}\text { ПривФО + УралФО + } \\
\text { СибФО }\end{array}$ & $\begin{array}{c}1 / 3 \\
(33 \%)\end{array}$ & - & - & - & - & - & - & $\begin{array}{c}5 \\
(33 \%)\end{array}$ & - & - & - & - & - & $\begin{array}{c}20 \\
(33 \%)\end{array}$ & - & - \\
\hline ЮФО + СКФО & $\begin{array}{c}1 / 2 \\
(50 \%)\end{array}$ & - & - & - & - & - & $\begin{array}{l}- \\
\mathrm{O} \text { в е }\end{array}$ & c $\quad(n=$ & $\begin{array}{l}2,5 \\
(50 \%) \\
=8)\end{array}$ & - & - & - & - & $\begin{array}{c}15 \\
(50 \%)\end{array}$ & - & - \\
\hline $\begin{array}{l}\text { ЦФО + ПривФО + } \\
\text { СибФО }\end{array}$ & $\begin{array}{c}4 / 4 \\
(100 \%)\end{array}$ & - & - & - & $\begin{array}{l}2 \text { и } 35 \\
(50 \%)\end{array}$ & $\begin{array}{c}34 \\
(25 \%)\end{array}$ & $\begin{array}{c}8 \\
(25 \%)\end{array}$ & - & $\begin{array}{c}3 \\
(25 \%)\end{array}$ & - & - & $\begin{array}{l}<\text { ПКО } \\
(25 \%)\end{array}$ & $\begin{array}{c}<\text { ПКО } \\
(25 \%)\end{array}$ & $\begin{array}{l}9-86 ; 27 \\
(100 \%)\end{array}$ & - & - \\
\hline ЮФО + СКФО & $\begin{array}{c}4 / 4 \\
(100 \%)\end{array}$ & - & - & - & - & - & - & $\begin{array}{l}<\text { ПКО } \\
(50 \%)\end{array}$ & - & - & - & $\begin{array}{c}6 \\
(25 \%)\end{array}$ & - & $\begin{array}{c}2-38 ; 14 \\
(75 \%)\end{array}$ & - & - \\
\hline $\begin{array}{l}\text { П р и м е ч а н и е. ДС } \\
\text { альтернариол, АМЭ } \\
\text { образцов, контамини } \\
\text { чественного определ } \\
\text { Приволжский федер } \\
\text { Южный федеральны }\end{array}$ & $\begin{array}{l}\text { ОН - дезокси } \\
- \text { метиловый } \\
\text { ированных мик } \\
\text { Іения; прочерк } \\
\text { ральный округ, } \\
\text { Ій округ, СКФс }\end{array}$ & $\begin{array}{l}\text { иниваленол, } \\
\text { эфир АОН, } \\
\text { сотоксином, } \\
\text { означает, чา } \\
\text { УралФО - } \\
\text { О - Северо- }\end{array}$ & $\begin{array}{r}\text { 3ЕА - } \\
\text { ТЕ - те } \\
\text { было мен } \\
\text { то микот } \\
\text { Уральски } \\
\text {-Кавказск }\end{array}$ & $\begin{array}{l}\text { зеарал } \\
\text { гентокс } \\
\text { нее } 3, \text { } \\
\text { гоксин } \\
\text { ий фед } \\
\text { кий фе }\end{array}$ & $\begin{array}{l}\text { енон, НІ } \\
\text { син, ЦТ } \\
\text { вместо ди } \\
\text { н не обна } \\
\text { деральны } \\
\text { едеральн }\end{array}$ & $\begin{array}{l}\text { ЕОС - не } \\
\text { В - цитре } \\
\text { иапазона к } \\
\text { ружен (со } \\
\text { Iй округ, } \\
\text { ый округ. }\end{array}$ & $\begin{array}{l}\text { неосолани } \\
\text { еовиридц } \\
\text { концентр } \\
\text { одержани } \\
\text { СибФО }\end{array}$ & $\begin{array}{l}\text { иол, ОТ } \\
\text { ин, МФІ } \\
\text { рации и } \\
\text { е ниже г } \\
\text { - Сибиг }\end{array}$ & $\begin{array}{l}A-\text { ох } \\
\text { К - ми } \\
\text { среднег } \\
\text { предела } \\
\text { iрский }\end{array}$ & $\begin{array}{l}\text { хратоксин А, } \\
\text { икофенолова } \\
\text { го указано сод } \\
\text { а обнаружени } \\
\text { федеральный }\end{array}$ & $\begin{array}{l}\text { ЦИТ - } \\
\text { яя кислота } \\
\text { держание } \\
\text { 1я, < ПО). } \\
\text { округ, Д }\end{array}$ & $\begin{array}{l}\text { итринин, Ф } \\
\text { Условия де } \\
\text { налита в кон } \\
\text { ЦФО - Цен } \\
\text { ФО - Даль }\end{array}$ & $\begin{array}{l}\text { ФВ } 2- \\
\text { ктирован } \\
\text { еетных о } \\
\text { альный } \\
\text { зосточнь }\end{array}$ & $\begin{array}{l}\text { - фумонизины } \\
\text { ния см. в таблиц } \\
\text { образцах. ПКО - } \\
\text { федеральный ок } \\
\text { ый федеральный }\end{array}$ & $\begin{array}{l}31 \text { и } \text { В }_{2} \\
\text { це } 1 . \text { Ес } \\
- \text { преде } \\
\text { круг, П } \\
\text { округ, }\end{array}$ & $\begin{array}{l}\text {, АОН - } \\
\text { сли числс } \\
\text { елы коли- } \\
\text { ривФО - } \\
\text { ЮФО }\end{array}$ \\
\hline
\end{tabular}


Загрязненность проб из Южного и Северо-Кавказского федеральных округов различалась для разных зерновых культур. Отличительной особенностью ячменя стало обнаружение ФВ1 в двух образцах из 6 исследованных. Случаи выявлении ФВ1 в продовольственном зерне ячменя зафиксированы в Тунисе (46 мкг/кг, один из 31 образца) (61) и в Польше (один из 8 образцов) (62). Мониторинг микотоксинов в фуражном зерна ячменя урожаев 2004-2014 годов из Центрального, Южного и Северо-Кавказского федеральных округов выявил ФВ1 в 19-79 \% образцов (31). Более того, в литературе описаны нетипичные для продовольственного зерна случаи детектирования ФВ в фуражном зерне пшеницы: $6 \%$ образцов урожая 2017 года содержали ФВ в количестве от 75 до 1990 мкг/кг (63); доля положительных образцов фуражной пшеницы урожаев 2004-2014 годов на юге России достигала 50 \% (31). Заслуживает внимания тот факт, что изученные нами образцы ячменя, овса и ржи не содержали ДОН даже в следовых количествах. Эти данные согласуются с результатами многолетнего мониторинга: в период с 2009 по 2016 года мы проанализировали 50 образцов ржи, 28 проб овса из Приволжского, Уральского и Сибирского федеральных округов и 12 проб ячменя из Центрального федерального округа. При этом ни в одной из исследованных проб ДОН не обнаружили, тогда как по данным О.П. Гавриловой с соавт. (44), встречаемость ДОН в ячмене из Уральского региона составляла $20 \%$, также был выявлен НИВ. Один из исследованных нами образцов ячменя из Краснодарского края не соответствовал требованиям безопасности по содержанию ОТА (11 мкг/кг).

4. Примеры совместной контаминации микотоксинами образцов продовольственного зерна из Амурской области урожаев разных лет (Дальневосточный федеральный округ)

\begin{tabular}{|c|c|c|c|c|c|c|c|c|c|c|c|c|}
\hline \multirow{2}{*}{ Образец, год } & \multicolumn{12}{|c|}{ Содержание, мкг/кг } \\
\hline & ДОН & 3-АцДОН & 15-АшДОН & 3EA & $\beta-3 Е Л$ & $\mathrm{~T}-2$ & HT-2 & OTA & ЦИТ & СТЦ & $\mathrm{AOH}$ & $\mathrm{TE}$ \\
\hline Пшеница, 2018 & 430 & 71 & 36 & - & - & - & - & - & - & - & 26 & 17 \\
\hline Пшеница, 2018 & 530 & 14 & - & - & 366 & 5 & 13 & - & - & - & - & 90 \\
\hline Ячмень, 2018 & $2830^{\mathrm{a}}$ & 65 & 54 & - & - & - & - & - & - & - & 40 & - \\
\hline Овес, 2016 & 650 & 5 & - & 180 & - & 2 & 12 & $9^{\mathrm{a}}$ & 30 & 120 & Нет да & нных \\
\hline $\begin{array}{l}\text { Пр и м е ч а н и } \\
\text { токсин А, ЦИТ } \\
\text { детектирования } \\
\text { предела обнарух }\end{array}$ & До & $\begin{array}{l}\mathrm{H}-\text { дезок } \\
\text { оинин, СТ } \\
\text { таблице } 1 \\
<\text { ПО); а }\end{array}$ & $\begin{array}{l}\text { инивале } \\
- \text { стер } \\
\text { Прочер } \\
\text { превыш }\end{array}$ & $\begin{array}{l}\text { ЗЕА } \\
\text { тоци } \\
\text { нача } \\
\text { мак }\end{array}$ & зеар & & $\begin{array}{l}\beta-3 Е Л \\
\text { Іьтерна } \\
\text { ксин н } \\
\text { устимо }\end{array}$ & - & ap & оол & & $\begin{array}{l}\text { охра- } \\
\text { Іовия } \\
\text { ниже }\end{array}$ \\
\hline
\end{tabular}

С точки зрения разнообразия детектируемых микотоксинов и частоты их обнаружения особый интерес вызывает зерно из Дальневосточного федерального округа. В таблице 4 приведены профили трех индивидуальных образцов зерна продовольственной пшеницы и ячменя урожая 2018 года, наиболее наглядно отражающие наблюдаемую в регионе множественную контаминацию микотоксинами. Дополнительно представлен один образец овса урожая 2016 года, также выделившийся разнообразием микотоксинов за период проводимого нами многолетнего мониторинга. Все образцы получены из Амурской области. Эти данные свидетельствуют о том, что на указанной территории в агробиоценозах сложились условия, способствующие заражению зерна микромицетами и токсинообразованию. Например, только в образцах из этого региона наряду с ДОН были обнаружены оба ацетильных производных ДОН (3- и 15-АщДОН), производное ЗЕА $\beta$-ЗЕЛ; одновременная контаминация восемью микотоксинами была показана для образца овса урожая 2016 года, в частности были выявлены пара ОТА + ЦИТ и СТЦ.

Т.Ю. Гагкаева с соавт. (21) обратили внимание на высокую зараженность зерна яровой пшеницы и ячменя, выращенного в Амурской 
области в 2019 году. В образцах они обнаружили ДОН (912-13343 мкг/кг), 3-АцДОН (0-293 мкг/кг), 15-АцДОН (19-179 мкг/кг), 3-глюкозид ДОН (98-3803 мкг/кг), ЗЕА (92-3670 мкг/кг) и монилиформин (5-218 мкг/кг); на уровне десятков микрограммов на один килограмм зерна были выявлены АОН и АМЭ, Т-2 и НТ-2 токсины; при этом АФЛ, ОТА, СТЦ, ЦПК, МФК, НЕОС, ДАС и ФУЗХ не были детектированы. Одна из особенностей контаминации зерна в Дальневосточном федеральном округе - частое выявление 3-АцДОН. По имеющимся данным (21), содержание ДНК гриба $F$. graminearum 3-АцДОН-генотипа в зерне из Амурской области оказалось в среднем в 1,1-1,3 раза выше, чем содержание ДНК 15-АцДОН-генотипа.

В представленном нами исследовании в единичных случаях в образцах зерна были обнаружены СТЦ, $\beta$-ЗЕЛ и ЦТВ. В частности, впервые получены данные о контаминации продовольственного зерна цитреовиридином в Российской Федерации. Этот микотоксин детектировали в пробах из Краснодарского края (по 56 мкг/кг в образцах пшеницы и кукурузы и 10 мкг/кг в одном образце ячменя). Частота обнаружения ЦТВ в зерновых в Краснодарском крае составила $12 \%$. Известно, что ЦТВ продуцируют микромицеты родов Penicillium и Aspergillus, главным образом P. citreonigrum, традиционно его обнаруживают в рисе. Например, содержание токсина в рисе из Бразилии достигало 97 мкг/кг (64), что сравнимо с уровнями контаминации исследованных нами образцов. ЦТВ способен накапливаться в организме и оказывать патологическое действие на центральную нервную систему (65). СТЦ обнаружен в двух образцах зерна - пшеницы из Липецкой области (1,3 мкг/кг) и ржи из Саратовской области $(0,1$ мкг/кг). Согласно данным литературы, встречаемость СТЦ в зерне пшеницы, ржи и кукурузы в странах умеренного климата достигала $7 \%$, гораздо чаще СТЦ детектировали в ячмене (до $44 \%$ проб) и овсе (до 57 \% проб) (38). $\beta$-ЗЕЛ (366 мкг/кг) мы выявили в одном образце пшеницы из Амурской области. Структурные аналоги ЗЕА - $\alpha$-ЗЕЛ и $\beta$-ЗЕЛ детектировали в зерне редко, систематические данные по этим микотоксинам в литературе отсутствуют.

Среди изученных 28 микотоксинов в исследованных образцах зерна мы не обнаружили НИВ, ФУЗХ, Т-2 триол, $\alpha$-ЗЕЛ, АФЛ и ЦПК. Согласно данным из Италии (66), Польши (62) и Чехии (67), частота выявления этих микотоксинов в пшенице не превышает $12 \%$. НИВ чаще контаминирует овес и ячмень (68). В настоящем исследовании ни в одном из видов зерна НИВ и ФУЗХ обнаружены не были. Фузариотоксины Т-2 триол и $\alpha$-3ЕЛ также редко выявляют в зерне, а АФЛ чаще детектируют в зерне из стран с субтропическим и тропическим климатом, например из Сирии (66) и стран Африки (69). Однако стоит иметь в виду, что рост среднегодовых температур и частые летние засухи в странах Южной Европы дают основания для неблагоприятных прогнозов контаминации кукурузы Aspergillus flavus и, следовательно, накопления АФЛ (70). Можно предположить, что подобный сценарий возможен в Южном и Северо-Кавказском федеральных округах Российской Федерации. ЦПК также относится к метаболитам Penicillium и Aspergillus, характерных для тропической и экваториальной зон. В литературе описаны случаи совместного обнаружения АФЛ и ЦПК в сельскохозяйственной продукции из жарких стран, например в кукурузе (71). Для последнего на примере кормового зерна кукурузы, ячменя и пшеницы показана низкая встречаемость на территории Российской Федерации: циклопиазоновая кислота была детектирована только в 3 из 276 образцов $(1,1 \%)$ при содержании 50-80 мкг/кг (72).

Таким образом, в России продовольственное зерно пшеницы урожая 
2018 года было преимущественно контаминировано фузариотоксинами дезоксиниваленолом (ДОН), зераленоном (ЗЕА), Т-2 и НТ-2 токсинами и метаболитами Alternaria тентоксином (ТЕ), альтернариолом (АОН) и его метиловым эфиром (АМЭ), также выявлены охратоксин А (ОТА), цитринин (ЦИТ) и микофеноловая кислота (МФК). При этом в пшенице из Центрального, Приволжского, Уральского и Сибирского федеральных округов превалировали альтернариатоксины, в первую очередь ТЕ, частота обнаружения которого варьировала от 62 до $91 \%$. Более половины образцов из Краснодарского края содержали ДОН, в двух из 15 исследованных образцов содержание ДОН превышало МДУ; при этом частота обнаружения ТЕ составила $13 \%$. Наряду с ДОН, среди регламентируемых микотоксинов, в 7 из 115 исследованных образцов (6 \%), был обнаружен ОТА, причем в двух с превышением МДУ. Большинство образцов пшеницы, контаминированных ОТА, были получены из Сибирского федерального округа. В 61 \% образцов пшеницы из Северо-Кавказского федерального округа и 87 \% образцов из Ростовской области микотоксины выявлены не были; в других регионах контаминированными оказались более половины образцов. Превышение МДУ зафиксировано по ДОН для трех образцов (2,6 \%), по ОТА - для двух $(1,7$ \%). В образцах кукурузы из Южного и Северо-Кавказского федеральных округов основными контаминантами были фумонизины В1 и В2

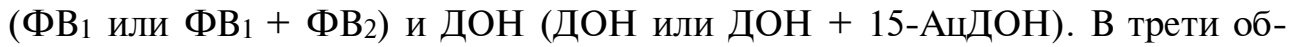
разцов была выявлены МФК и неосоланиол (НЕОС). В единичных случаях обнаружены 3ЕА, Т-2 и НТ-2, ОТА, ЦИТ, цитреовиридин (ЦТВ). Токсины Alternaria детектированы не были. Все исследованные образцы, за исключением одного, соответствовали требованиям безопасности (в образце из Краснодарского края был превышен МДУ по ОТА). Среди фузариотоксинов в зерне ячменя были выявлены Т-2 и НТ-2, а также ФВ1 в образцах из южных регионов России; токсины Alternaria оказались более характерны для образцов из Центрального, Приволжского, Уральского и Сибирского федеральных округов. В единичных случаях обнаружены ЦИТ, ЦТВ и ОТА, причем последний - с превышением МДУ. В образцах зерна ржи и овса, вне зависимости от региона, чаще других микотоксинов обнаруживали альтернариатоксины, преимущественно ТЕ. Также выявлены Т-2 и НТ-2 токсины, НЕОС, ЦИТ. В одном образце ржи содержание ОТА не соответствовало требованиям безопасности. Исследованные образцы зерна ячменя, овса и ржи не были контаминированы ДОН даже в следовых количествах. Впервые получены данные о контаминации ЦТВ продовольственного зерна кукурузы, ячменя и пшеницы, выращенного на территории Российской Федерации. В исследованных образцах зерна прослеживается зависимость набора выявляемых микотоксинов от вида культуры и региона ее возделывания. Обращает на себя внимание высокая частота обнаружения ОТА и превышение МДУ в $45 \%$ образцов продовольственного зерна, загрязненных этим микотоксином.

Авторы благодарят работников Федеральной службы по надзору в сфере защиты прав потребителей и благополучия человека, ее региональных Центров гигиены и эпидемиологии за многолетнее сотрудничество, отбор и предоставление проб зерна и продуктов его переработки для исследований в ФГБУН ФИЦ питания и биотехнологии. Авторы также выражают признательность рецензенту за замечания и предложения, которые в значительной степени способствовали структурированию изложения результатов и более полному их обсуждению.

\section{ЛИТ ИРАТ У РА}

1. Pitt J.I., Miller J.D. A concise history of mycotoxin research. Journal of Agricultural and Food 
Chemistry, 2017, 65(33): 7021-7033 (doi: 10.1021/acs.jafc.6b04494).

2. Технический регламент Таможенного союза ТР ТС 015/2011 «О безопасности зерна», 2011. Режим доступа: https://docs.cntd.ru/document/90232039). Без даты.

3. Технический регламент Таможенного союза ТР ТС 021/2011 «О безопасности пищевой продукции», 2011. Режим доступа: https://docs.cntd.ru/document/902320560). Без даты.

4. Sulyok M., Berthiller F., Krska R., Schuhmacher R. Development and validation of a liquid chromatography/tandem mass spectrometric method for the determination of 39 mycotoxins in wheat and maize. Rapid Commun. Mass Spectrometry, 2006, 20(18): 2649-59 (doi: 10.1002/rcm.2640).

5. Sulyok M., Krska R., Schuhmacher R. Application of a liquid chromatography-tandem mass spectrometric method to multi-mycotoxin determination in raw cereals and evaluation of matrix effects. Food Additives and Contaminants, 2007, 24(10): 1184-1195 (doi: 10.1080/02652030701510004).

6. Malachova A., Stranska M., Vaclavikova M., Elliott C. T., Black C., Meneely J., Hajslova J., Ezekiel C. N., Schuhmacher R., Krska R. Advanced LC-MS-based methods to study the cooccurrence and metabolization of multiple mycotoxins in cereals and cereal-based food. Analytical and Bioanalytical Chemistry, 2018, 410(3): 801-825 (doi: 10.1007/s00216-017-0750-7).

7. Steiner D., Sulyok M., Malachovб A., Mueller A., Krska R. Realizing the simultaneous liquid chromatography-tandem mass spectrometry based quantification of $>1200$ biotoxins, pesticides and veterinary drugs in complex feed. Journal of Chromatography A, 2020, 1629: 461502 (doi: 10.1016/j.chroma.2020.461502).

8. Amelin V., Korotkov A., Andoralov A. Identification and determination of 492 contaminants of different classes in food and feed by high-resolution mass spectrometry using the standard addition method. Journal of AOAC International, 2016, 99(6): 1600-1618 (doi: 10.5740/jaoacint. 16-0069).

9. Comission Regulation (EU) No 165/2010 amending Regulation No 1881/2006 setting maximum levels for certain contaminants in foodstuffs as regards aflatoxins. 2010. Режим доступа: https://eurlex.europa.eu/LexUriServ/LexUriServ.do?uri=OJ:L:2010:050:0008:0012:EN:PDF). Без даты.

10. Alexander J., Barregerd L., Bignami M., Brüschweiler B., Ceccatelli S., Cottrill B., Dinovi M., Edler L., Grasl-Kraupp B., Hogstrand Ch., Hoogenboom L., Knutsen H.K., Nebbia C.S., Oswald I.P., Petersen A., Rose M., Roudot A.-C., Schwerdtle T., Vleminckx Ch., Vollmer G., Wallace H. Risks to human and animal health related to the presence of deoxynivalenol and its acetylated and modified forms in food and feed. EFSA Journal, 2017, 15(9): 4718 (doi: 10.2903/j.efsa.2017.4718).

11. Alexander J., Barregerd L., Bignami M., Bruschweiler B., Ceccatelli S., Cottrill B., Dinovi M., Edler L., Grasl-Kraupp B., Hogstrand Ch., Hoogenboom L., Knutsen H.K., Nebbia C.S., Oswald I.P., Petersen A., Rogiers V.M., Rose M., Roudot A.-C., Schwerdtle T., Vleminckx Ch., Vollmer G., Wallace H. Appropriateness to set a group health based guidance value for T2 and HT2 toxin and its modified forms. EFSA Journal, 2017, 15(1): 04655 (doi: 10.2903/j.efsa.2017.4655).

12. Alexander J., Barregard L., Bignami M., Ceccatelli S., Cottrill B., Dinovi M., Edler L., GraslKraupp B., Hogstrand Ch., Hoogenboom L., Knutsen H.K., Nebbia C.S., Oswald I.P., Petersen A., Rogiers V.M., Rose M., Roudot A.-C., Schwerdtle T., Vleminckx Ch., Vollmer G., Wallace H. Appropriateness to set a group health-based guidance value for zearalenone and its modified forms. EFSA Journal, 2016, 14(4): 4425 (doi: 10.2903/j.efsa.2016.4425).

13. Knutsen H-K., Barregerd L., Bignami M., Brüschweiler B., Ceccatelli S., Cottrill B., Dinovi M., Edler L., Grasl-Kraupp B., Hogstrand Ch., Hoogenboom L., Nebbia C. S., Petersen A., Rose M., Roudot A.-C., Schwerdtle T., Vleminckx Ch., Vollmer G., Wallace H., Dall'Asta Ch., Gutleb A.C, Humpf H.-U., Galli C., Metzler M., Oswald I.P., Parent-Massin D., Binaglia M., Steinkellner H., Alexander J. Appropriateness to set a group health-based guidance value for fumonisins and their modified forms. EFSA Journal, 2018, 16(2): 5172 (doi: 10.2903/j.efsa.2018.5172).

14. Гагкаева Т.Ю., Ганнибал Ф.Б., Гаврилова О.П. Зараженность зерна пшеницы грибами Fusarium и Alternaria на юге России в 2010 году. Защита и карантин растений, 2012, 1: 37-41.

15. Khaneghah A.M., Martins L.M., von Hertwig A.M., Bertoldo R., Sant'Ana A.S. Deoxynivalenol and its masked forms: Characteristics, incidence, control and fate during wheat and wheat based products processing - a review. Trends Food Science and Technol., 2018, 71: 13-24 (doi: 10.1016/j.tifs.2017.10.012).

16. Yli-Mattila T. Ecology and evolution of toxigenic Fusarium species in cereals in Nothern Europe and Asia. Journal of Plant Pathology, 2010, 92(1): 7-18 (doi: 10.4454/jpp.v92i1.10).

17. Гагкаева Т.Ю., Гаврилова О.П., Левитин М.М. Биоразнообразие и ареалы основных токсинопродуцирующих грибов рода Fusarium. Биосфера, 2014, 6(1): 36-45.

18. Tutelyan V.A., Zaharova L.P., Sedova I.B., Perederyaev O.I., Aristarkhova T.V., Eller K.I. Fusariotoxins in Russian Federation 2005-2010 grain harvests. Food Additives and Contaminants: Part B, 2013, 6(2): 139-145 (doi: 10.1080/19393210.2013.767862).

19. Захарова Л.П., Седова И.Б., Аристархова Т.В., Передеряев О.И., Селифанов А.В., Эллер К.И., Тутельян В.А. Фузариотоксины в зерновой продукции Российской Федерации: ситуация 2006-2008 годов. Вопросы питания, 2009, 78(6): 26-31.

20. Седова И.Б., Аксенов И.В., Захарова Л.П. Результаты мониторинга контаминации 
продовольственного зерна урожаев 2012-2014 годов микотоксинами. Вопросы питания, 2016, 85(S2): 35 .

21. Гагкаева Т.Ю., Гаврилова О.П., Орина А.С., Гогина Н.Н. Чрезвычайная ситуация 2019 года и болезни зерна в Амурской области. Защита и карантин растений, 2020, 8: 19-21.

22. Гагкаева Т.Ю., Гаврилова О.П. Фузариоз зерновых культур. Защита и карантин растений, 2009, 12: 13-15.

23. van der Lee T., Zhang H., van Diepeningen A., Waalwijk C. Biogeography of Fusarium graminearum species complex and chemotypes: a review. Food Additives and Contaminants: Part $A$, 2015, 32(4): 453-460 (doi: 10.1080/19440049.2014.984244).

24. Chen P., Xiang B., Shi H., Yu P., Song Y., Li Sh. Recent advances on type A trichothecenes in food and feed: analysis, prevalence, toxicity, and decontamination techniques. Food Control, 2020, 118: 107371 (doi: 10.1016/j.foodcont.2020.107371).

25. Гагкаева Т.Ю., Гаврилова О.П. Зараженность зерна грибами Fusarium в Краснодарском и Ставропольском краях. Защита и карантин растений, 2014, 3: 30-32.

26. Гаврилова О.П., Гагкаева Т.Ю. Новые сведения о распространении на территории России гриба Fusarium langsethiae, продуцирующего Т-2 и НТ-2 токсины. Вестник защиты растений, 2020, 103(3): 201-206 (doi: 10.31993/2308-6459-2020-103-3-13282).

27. Гаврилова О.П., Орина А.С., Гогина Н.Н., Гагкаева Т.Ю. Проблема фузариоза зерна в Зауралье: ретроспектива исследований и современная ситуация. Аграрный вестник Урала, 2020, 07(198): 29-40 (doi: 10.32417/1997-4868-2020-198-7-29-40).

28. Kis M., Vulic A., Kudumija N., Sarkanj B., Jaki Tkalec V., Aladic K., Skrivanko M., Furmeg S., Pleadin J. A two-year occurrence of fusarium T-2 and HT-2 toxin in Croatian cereals relative of the regional weather. Toxins, 2021, 13(1): 39 (doi: 10.3390/toxins13010039).

29. Zinedine A., Soriano J. M., Molto J. C., Manes J. Review on the toxicity, occurrence, metabolism, detoxification, regulations and intake of zearalenone: an oestrogenic mycotoxin. Food and Chemical Toxicology, 2007. 45(1): 1-18 (doi: 10.1016/j.fct.2006.07.030).

30. Седова И.Б., Захарова Л.П., Киселева М.Г., Чалый З.А., Тутельян В.А. Фузариотоксины и афлатоксин В1 в продовольственном зерне кукурузы в РФ. Научные труды СКФНЦСВВ, 2018, 21: 129-137.

31. Дробин Ю.Д., Солдатенко Н.А., Сухих Е.А., Коваленко А.В. Итоги мониторинга контаминации фуражного зерна пшеницы, ячменя и кукурузы на юге России. Проблемы ветеринарной санитарии, гигиены и экологии, 2015, 4 (16): 27-30.

32. Аксенов И.В., Эллер К.И., Тутельян В.А. Содержание охратоксина А в продовольственном зерне урожая 2003 и 2004 годов. Вопросы питания, 2006, 75(1): 43-47.

33. Palumbo R., Crisci A., Venancio A., Cortinas Abrahantes J., Dorne J. L., Battilani P., Toscano P. Occurrence and co-occurrence of mycotoxins in cereal-based feed and food. Microorganisms, 2020, 8(1): 74 (doi: 10.3390/microorganisms8010074).

34. Alexander J., Benford D., Boobis A., Ceccatelli S., Cottrill B., Cravedi J.-P., Di Domenico A., Doerge D., Dogliotti Eu., Edler L., Farmer P., Filipi M., Fink-Gremmels J., Fürst P., Guérin Th., Knutsen H.K., Machala M., Mutti A., Schlatter J., Rose M., van Leeuwen R. Scientific opinion on the risks for animal and public health related to the presence of Alternaria toxins in feed and food. EFSA Journal, 2011, 9(10): 2407 (doi: 10.2903/j.efsa.2011.2407).

35. Gagkaeva T., Gavrilova O., Orina A., Burkin A., Khusaynov Kh. Microbiological quality of grain cultivated in the North Caucasus region in 2019. BIO Web of Conferences, 2020, 27: 00151 (doi: 10.1051/bioconf/20202700151).

36. Ганнибал Ф.Б. Изучение факторов, влияющих на развитие альтернариоза у зерна злаков, возделываемых в европейской части России. Сельскохозяйственная биология, 2018, 53(3): 605-615 (doi: 10.15389/agrobiology.2018.3.605rus).

37. Орина А.С., Гаврилова О.П., Гагкаева Т.Ю., Ганнибал Ф.Б. Микромицеты Alternaria spp. и Bipolaris sorokiniana и микотоксины в зерне, выращенном в Уральском федеральном округе. Микология и фитопатология, 2020, 54(5): 365-377 (doi: 10.31857/s0026364820050086).

38. Седова И.Б., Киселева М.Г., Захарова Л.П., Тутельян В.А. Токсиколого-гигиеническая характеристика микотоксина стеригматоцистина и методы его определения в пищевых продуктах. Гигиена и санитария, 2019, 98(1): 105-117 (doi: 10.18821/0016-9900-2019-98-1105-117).

39. Benford D., Ceccatelli S., Cottrill B., DiNovi M., Dogliotti E., Edler L., Farmer P., Fürst P., Hoogenboom L., Knutsen H.K., Haldorsen A-K.L., Metzler M., Nebbia C.S., O’Keeffe M., Rietjens I., Schrenk D., Silano V., van Loveren H., Vleminckx Ch., Wester P. Scientific opinion on the risk for public and animal health related to the presence of sterigmatocystin in food and feed. EFSA Journal, 2013, 11(6): 3254 (doi: 10.2903/j.efsa.2013.3254).

40. Zhao Y., Wang Q., Huang J., Ma L., Chen Z., Wang F. Aflatoxin B1 and sterigmatocystin in wheat and wheat products from supermarkets in China. Food Additives and Contaminants: Part B, 2018, 11(1): 9-14 (doi: 10.1080/19393210.2017.1388295).

41. Kononenko G.P., Burkin A.A. Peculiarities of feed contamination with citrinin and ochratoxin A. Agricultural Sciences, 2013, 4(1): 34-38 (doi: 10.4236/as.2013.41006). 
42. Gruber-Dorninger C., Novak B., Nagl V., Berthiller F. Emerging mycotoxins: beyond traditionally determined food contaminants. Journal of Agricultural and Food Chemistry, 2017, 65(33): 7052-7070 (doi: 10.1021/acs.jafc.6b03413).

43. Moldes-Anaya A.S., Asp T.N, Eriksen G.S., Skaar I., Rundberget T. Determination of cyclopiazonic acid in food and feeds by liquid chromatography-tandem mass spectrometry. Journal of Chromatography A, 2009, 1216(18): 3812-3818 (doi: 10.1016/j.chroma.2009.02.061).

44. Гаврилова О.П., Орина А.С., Гогина Н.Н., Гагкаева Т.Ю. Совместная встречаемость метаболитов грибов Alternaria и Fusarium, ассоциированных с зерновыми культурами. Российская сельскохозяйственная наука. 2020, 6: 20-23 (doi: 10.31857/S2500262720060058).

45. Burkin A.A., Kononenko G.P. Producers of mycophenolic acid in ensiled and grain feeds. Applied Biochemistry and Microbiology, 2010, 46(5): 545-550 (doi: 10.1134/S0003683810050145).

46. Буркин А.А., Устюжанина М.И., Зотова Е.В., Кононенко Г.П. Причины контаминации производственных партий семян подсолнечника (Helianthus annuus L.) микотоксинами. Сельскохозяйственная биология. 2018, 53(5): 969-976 (doi: 10.15389/agrobiology.2018.5.969rus).

47. Shaw L.M., Figurski M., Milone M.C., Trofe J., Bloom R.D. Therapeutic drug monitoring of mycophenolic acid. Clinical Journal of the American Society of Nephrology, 2007, 2(5): 1062-1072 (doi: 10.2215/CJN.03861106).

48. Киселева М.Г., Чалый 3.А., Седова И.Б., Минаева Л.П., Шевелева С.А. Изучение загрязненности чая и чайных травяных напитков микотоксинами (Сообщение 2). Анализ риска здоровью, 2020, 1: 38-51 (doi: 10.21668/health.risk/2020.1.04).

49. Чалый 3.А., Киселева М.Г., Седова И.Б., Минаева Л.П., Шевелева С.А., Тутельян В.А. Изучение контаминации сухофруктов микотоксинами. Вопросы питания, 2021, 90(1): 33 39 (doi: 10.33029/0042-8833-2021-90-1-33-39).

50. Гагкаева Т.Ю., Гаврилова О.П., Орина А.С., Аблова И.Б., Беспалова Л.А. Маркерные метаболиты грибов Alternaria, Fusarium и Microdochium как инструмент оценки их взаимоотношений в микробиоте зерна пшеницы. Биотехнология и селекция растений, 2018 , 1(1): 7-15 (doi: 10.30901/2658-6266-2018-1-7-15).

51. Chen Ch., Frank K., Wang T., Wu F. Global wheat trade and Codex Alimentarius guidelines for deoxynivalenol: a mycotoxin common in wheat. Global Food Security, 2021, 29: 100538 (doi: 10.1016/j.gfs. 2021.100538).

52. Juan Ch., Covarelli L., Beccari G., Colasante V., Maces J. Simultaneous analysis of twentysix mycotoxins in durum wheat grain from Italy. Food Control, 2016, 62: 322-329 (doi: 10.1016/j.foodcont.2015.10.032).

53. Müller M.E.H., Korn U. Alternaria mycotoxins in wheat - a 10 years survey in the Northeast of Germany. Food Control, 2013, 34(1): 191-197 (doi: 10.1016/j.foodcont.2013.04.018).

54. Khaneghah A.M., Farhadi M., Nematollahi A., Vasseghian Y., Fakhri Y. A systematic review and meta-analysis to investigate the concentration and prevalence of trichothe-cenes in the cereal-based food. Trends in Food Science \& Technology, 2020, 102: 193-202 (doi: 10.1016/j.tifs.2020.05.026).

55. Chen P., Xiang B., Shi H., Yu P., Song Y., Li Sh., Recent advances on type A trichothecenes in food and feed: analysis, prevalence, toxicity, and decontamination techniques. Food Control, 2020. 118: 107371 (doi: 10.1016/j.foodcont.2020.107371).

56. Oliveira M.S., Rocha A., Sulyok M., Krska R., Mallmann C.A. Natural mycotoxin contamination of maize (Zea mays L.) in the South region of Brazil. Food Control, 2017, 73: 127-132 (doi: 10.1016/j.foodcont.2016.07.033).

57. Кононенко Г.П., Буркин А.А., Зотова Е.В. Микотоксикологический мониторинг. Сообщение 2. Зерно пшеницы, ячменя, овса, кукурузы. Ветеринария сегодня, 2020, 2(33): 139-145 (doi: 10.29326/2304-196X-2020-2-33-139-145).

58. Кононенко Г.П., Буркин А.А., Зотова Е.В., Смирнов А.М. Микотоксикологическое исследование кормового зерна кукурузы (1998-2018). Российская сельскохозяйственная наука, 2019, 3: 28-31 (doi: 10.31857/S2500-26272019328-31).

59. Hajnal E.J., Kos J., Malachova A., Steiner D., Stranska M., Krska R., Sulyok M. Mycotoxins in maize harvested in Serbia in the period 2012-2015. Part 2: non-regulated mycotoxins and other fungal metabolites. Food Chemistry, 2020, 317: 126409 (doi: 10.1016/j.foodchem.2020.126409).

60. Гаврилова О.П., Ганнибал Ф.Б., Гагкаева Т.Ю. Зараженность зерна овса грибами Fusarium и Alternaria и ее сортовая специфика в условиях северо-запада России. Сельскохозяйственная биология, 2016, 51(1): 111-118 (doi: 10.15389/agrobiology.2016.1.111rus).

61. Juan C., Berrada H., Manes J., Oueslati S. Multi-mycotoxin determination in barley and derived products from Tunisia and estimation of their dietary intake. Food and Chemical Toxicology, 2017, 103: 148-156 (doi: 10.1016/j.fct.2017.02.037).

62. Bryla M., Wa kiewicz A., Podolska G., Szymczyk K., Jedrzejczak R., Damaziak K., Sulek A. Occurrence of 26 mycotoxins in the grain of cereals cultivated in Poland. Toxins, 2016, 8(6): 16 (doi: 10.3390/toxins8060160).

63. Кононенко Г.П., Буркин А.А., Зотова Е.В., Устюжанина М.И., Смирнов А.М. Особенности контаминации зерна пшеницы и ячменя фузариотоксинами. Российская 
сельскохозяйственная наука, 2018, 1: 17-21.

64. Rosa C.A., Keller K.M., Oliveira A.A. Production of citreoviridin by Penicillium citreonigrum strains associated with rice consumption and beriberi cases in the Maranhro State, Brazil. Food Additives and Contaminants: Part A, 2010, 27(2): 241-248 (doi: 10.1080/19440040903289712).

65. Uchiyama Y., Takino M., Noguchi M., Shiratori N., Kobayashi N., Sugita-Konishi Y. The in vivo and in vitro toxicokinetics of citreoviridin extracted from P. citreonigrum. Toxins, 2019, 11(6): 360 (doi: 10.3390/toxins1 1060360).

66. Alkadri D., Rubert J., Prodi A., Pisi A., Manes J., Soler C. Natural co-occurrence of mycotoxins in wheat grains from Italy and Syria. Food Chemistry, 2014, 157: 111-118 (doi: 10.1016/j.foodchem.2014.01.052).

67. Chrpová J., Šíp V., Sumíková T., Salava J., Palicová J., Štočková L., Džuman Z., Hajšlová J. Occurrence of Fusarium species and mycotoxins in wheat grain collected in the Czech Republic. World Mycotoxin Journal, 2016, 9(2): 317-327 (doi: 10.3920/WMJ2015.1917).

68. Hietaniemi V., Rämö S., Yli-Mattila T., Jestoi M., Peltonen S., Kartio M., Sievilainen E., Koivisto T., Parikka P. Updated survey of Fusarium species and toxins in Finnish cereal grains. Food Additives \& Contaminants: Part A, 2016, 33(5): 831-848 (doi: 10.1080/19440049.2016.1162112).

69. Gruber-Dorninger C., Jenkins T., Schatzmayr G. Multi-mycotoxin screening of feed and feed raw materials from Africa. World Mycotoxin Journal, 2018, 11(3): 369-383 (doi: 10.3920/WMJ2017.2292).

70. Moretti A., Pascale M., Logrieco A.F. Mycotoxin risks under a climate change scenario in Europe. Trends in Food Science \& Technology, 2019, 84: 38-40 (doi: 10.1016/j.tifs.2018.03.008).

71. Hayashi Y., Yoshizawa T. Analysis of cyclopiazonic acid in corn and rice by a newly developed method. Food Chemistry, 2005, 93(2): 215-221 (doi: 10.1016/j.foodchem.2004.09.017).

72. Кононенко Г.П., Буркин А.А. Токсинообразующая способность грибов рода Aspergillus и оценка загрязненности циклопиазоновой кислотой кормовой продукции. Микология $u$ фитопатология, 2008, 42(2): 178-184.

\title{
${ }_{1}^{1}$ ФББУН Федеральный исследовательский центр питания, Поступила в редакцию биотехнологии и безопасности пищи, \\ 21 января 2021 года
}

119240 Россия, г. Москва, Устьинский пр., 2/4,

e-mail: mg_kiseleva@ion.ru $₫$, isedova@ion.ru, chalyyz@list.ru,

zaharova@ion.ru, t.aristarkhova@yandex.ru, tutelyan@ion.ru;

2ФГАОУ ВО Первый Московский государственный

медицинский университет им. И.М. Сеченова,

119992 Россия, г. Москва, ул. Трубецкая, 8/2

Sel'skokhozyaistvennaya biologiya [Agricultural Biology], 2021, V. 56, № 3, pp. 559-577

\section{MULTI-MYCOTOXIN SCREENING OF FOOD GRAIN PRODUCED IN RUSSIA IN 2018}

\author{
M.G. Kiseleva1, ${ }^{凶}$, I.B. Sedova1, Z.A. Chalyy1, L.P. Zakharova1, T.V. Aristarkhova1, \\ V.A. Tutelyan 1,2
}

${ }^{1}$ Federal Research Centre of Nutrition, Biotechnology and Food Safety, 2/14, Ust'yinskii per., Moscow, 109240 Russia,e-mailmg_kiseleva@ion.ru ( $₫$ corresponding author), isedova@ion.ru, chalyyz@list.ru, zaharova@ion.ru, t.aristarkhova@yandex.ru, tutelyan@ion.ru;

${ }^{2}$ Sechenov First Moscow State Medical University, 8/2, ul. Trubetskaya, Moscow, 119992 Russia

ORCID:

Kiseleva M.G. orcid.org/0000-0003-1057-0886

Sedova I.B. orcid.org/0000-0002-6011-4515

Chalyy Z.A. orcid.org/0000-0002-9371-8163

Zakharova L.P. orcid.org/0000-0001-7355-5259

Aristarkhova T.V. orcid.org/0000-0001-9496-8626

Tutelyan V.A. orcid.org/0000-0002-4164-8992

The authors declare no conflict of interests.

Acknowledgements:

The authors thank the employees of the Federal Service for Surveillance on Consumer Rights Protection and Human Welfare, its regional Centers for Hygiene and Epidemiology for many years of cooperation, collection and provision of grain and grain products. The authors also express their gratitude to the reviewer for comments and suggestions which greatly contributed to the structuring of the results and a more complete discussion.

The study was carried out within the framework of research program 0529-2018-0113 "Development of the methodological and regulatory framework to ensure modern requirements for the food quality and the development of technologies for assessing the effectiveness of specialized food products"

Received January 21, 2021

doi: 10.15389/agrobiology.2021.3.559eng

\section{Abstract}

Accumulation and analysis of data concerning mycotoxins in food grain, their co-occurrence and concentration are essential for health risk analysis and management. Mycotoxins were analyzed in 162 samples of food wheat, barley, maize, oat and rye harvested in seven Federal Districts: Central, 
Volga, Urals, Siberian, Far Eastern, Southern and Northern Caucasus in 2018. High-performance liquid chromatography coupled to tandem mass spectrometry was used to detect 28analytes: regulated mycotoxins (deoxynivalenol (DON), T-2 toxin (T-2), zearalenone (ZEA), fumonisins $\mathrm{B} 1$ and $\mathrm{B} 2$ (FB1 and $\mathrm{FB}_{2}$ ), aflatoxin $\mathrm{B}_{1}$ (AFL $\mathrm{B}_{1}$ ), ochratoxin A (OTA), their derivatives (3- and 15-Acetyl-DON, nivalenol (NIV), fusarenone X (FUSX), HT-2 toxin (HT-2), T-2 triol, neosolaniol (NEOS), $\alpha-$ and $\beta$-zearalenol ( $\alpha$ - and $\beta$-ZEL), aflatoxins B2, G1, G2 (AFL B2, G1, G2), sterigmatocystin (STC); $A l$ ternaria mycotoxins (tentoxin (TE), altenuene (ALT), alternariol (AOH), its methyl ether (AME)), citrinin (CIT), citreoviridin (CTV), mycophenolic (MPA) and cyclopiazonic (CPA) acids. Most wheat samples from Central, Volga, Urals and Siberian Federal Districts were positive for Alternaria toxins, while deoxynivalenol (DON) was discovered in the wheat from the Krasnodar region. ZEA, T-2 and HT-2, OTA, CIT and MPA were present in wheat samples also. FB1 or FB1 + FB2 and DON (DON or DON + 15-AcDON) prevailed in corn from the Southern and the Northern Caucasus regions. MPA and NEOS were detected in a third of studied corn samples, while Alternaria toxins were absent. Barley from the South of Russia was mostly contaminated with T-2 and HT-2 alongside FB1. Like wheat, most barley samples from Central, Volga, Urals and Siberian Federal Districts were positive for Alternaria toxins. The occurrence of Alternaria toxins in rye and oat samples was high regardless of region of origin. T-2 and HT-2, NEOS and CIT were detected in these samples also. However, DON was not found in any sample of barley, rye, or wheat. To the best of our knowledge, we are the first to report CTV in food grain of wheat, barley and corn from Russia. Thus, the detected mycotoxins pattern of food grain proved to depend on the crop and the grain origin. The results correlate well with reported data on fungal contamination of cereals and mycotoxins found in feed. High OTA occurrence ( $7.4 \%$ of all samples) with $45 \%$ positives over maximum level should be noted concerning safety assurance.

Keywords: food grain, wheat, barley, corn, rye, oat, mycotoxins; deoxynivalenol, T-2 and HT-2 toxins, zearalenone, fumonisins, aflatoxins, ochratoxin A, nivalenol, fusarenone X, T-2 triol, neosolaniol, zearalenols, sterigmatocystin, tentoxin, altenuene, alternariol, citrinin, citreoviridin, mycophenolic acid, cyclopiazonic acid; co-contamination, HPLC-MS/MS. 